\title{
Challenging BRICS mythology
}

Rosemary GaLLI

Patrick Bond and Ana Garcia have brought together in their co-edited book, BRICS: an Anti-Capitalist Critique, a formidable collection of academics who attempt to weigh the collective and individual stances, often contradictory, of the countries known as the BRICS nations: Brazil, Russia, India, China and South Africa. The objective is to ascertain whether the actions of these so-called emerging economies amount to a challenge to the present hierarchical, capitalist international order or simply moves to incorporate themselves into that hierarchy.

In the book's Introduction, Bond and Garcia outline four major perspectives (subdivided into ten variations) on the BRICS phenomenon and distinguish four categories or classes of people holding these views. Their categorization provides a very useful tool-a helpful starting point-for professors, students and the public alike for identifying biases in the ever-growing literature and journalistic reporting on the subject. The "BRICS from Above" position, espoused by politicians and statesmen, corporate and similar elites, incorporates those who characterize the BRICS as anti-imperialist, that is, against capitalist imperialism yet only on a rhetorical level; or as sub-imperialist, that is, as a junior partner to the United States, Europe or Japan; or as inter-imperialist promoting the imperial interests of the collective or dominant members vis-à-vis those of the United States and its allies.

Academics, intellectuals and so on take a "BRICS from the Middle" posture, some ally with "BRICS from Below" activists in their criticism of BRICS while others are pro the bloc and still others adopt a wait-and-see posture. The "Below" group with whom Bond and Garcia sympathize are activists opposing the bloc's imperialist tendencies in the context of local, national or "solidaristic-internationalist" struggles. Clearly, Bond and Garcia's project is to present arguments to strengthen the latter position. The fourth position 
they identify in the literature, is "pro-West business" found among those groups within individual BRICS states who see the bloc as a potential threat to the established international order with which they associate.

The book is divided into three sections: the first asks the question whether the BRICS play a sub-imperial, inter-imperial or capital-imperialist role in the global political economy. The second examines the actions of the BRICS as a unit and those of individual members in selected African, Latin American and Asian countries while the third section situates the BRICS in the framework of global capitalism.

What follows is a review of the argumentation as presented by the book's contributors. Patrick Bond opens the discussion on how to characterize the BRICS' position in the global political economy. He clearly sees the collective actions of the BRICS as sub-imperialism citing not only Rui Mauro Marini who first coined the term but Rosa Luxemburg's and David Harvey's works to support and expand Marini's thesis. Typical of sub-imperial powers have been regional resource extraction, export of capital and facilitation of domestic monopolies. Bond adds the additional roles of guaranteeing regional stability and advancing global neo-liberalism in international arenas such as the World Trade Organization and the Climate summits.

In his chapter, Mathias Luce has performed the impressive task of systematizing Marini's dispersed works on the analytical category of sub-imperialism. Marini defined it as the highest form of dependent capitalism in which the sub-imperialist social formation not only acts as a transmitter of surplus value to the imperialist center but is also able to appropriate surplus value from less developed countries for its own. In this way, it displaces some of the conditions of dependent capitalism and can claim relative autonomy. Marini focused primarily on Brazil and its developing status in the world economy. In bringing together the different elements in Marini's analysis, Luce is able to extend them to the economies of South Africa and India. In his view, China and Russia fall outside as poles of imperialistic tendencies. 
In her contribution, Virginia Fontes attacks the issue of the milieu in which sub-imperialism arises. If, as Luce argues, sub-imperialism is an advance on the school of thought known as Marxist Development Theory, then Fontes presents the reader with another such theoretical advance. She focuses not only on national social formations within the global capitalism but also the latter's development: specifically capitalist expansion via the integration of domestic social classes. She denominates this process, "capital-imperialism." It is not a neat historical process as it is driven by the contradictions inherent in capitalism especially as it collides with the aspirations and plans of various national social formations. Moreover, capital-imperialism is not simply an economic process but encompasses all spheres of existence although its essence remains the increase and appropriation of surplus value. Fontes then delineates three periods of advance.

After World War II capitalism moved beyond the need for territorial control to interconnecting national capitalisms in an informal empire. In the 1960 s and 70s, huge concentrations of capital occurred in all sectors requiring the subordination of large numbers of people as a working class. The proliferation of multilateral institutions transformed inter-state relations and legitimized capital-imperial transformation as 'development.' Moreover, the ideal of democracy was promulgated as concomitant with economic 'progress' and generated expectations, demands and consequently contradictions. Alongside the internationalization of capital came the internationalization of social struggles, exemplified by the French May 1968 rebellion. Since then, capital-imperialist states have sought to defuse such resistance by coopting them. Finally, capital-imperialist modes of social reproduction penetrated formerly subaltern states that then adopted the same attitudes and strategies: the BRICS "personify the most impressive pinnacle of subaltern countries elevated...to an industrialization and generalization of capitalist social relations that requires outward expansion (58)."

Leo Panitch does not disagree with Luce or Fontes on the integration of capitalist powers within the informal empire, within which the United States is the dominant imperial state. Despite the 
BRICS' support of the center's neo-liberal policies, Panitch asserts, they are not fully integrated in the imperial circle as they lack the military and security links of NATO states. In order to overturn the informal empire, he argues that social struggles need to focus on shifting "the balance of class forces inside the US itself (67)."

In contrast to Panitch, Claudio Katz sees the emergence of China as a central global power as shown by its phenomenal economic growth and is pivotal role in supporting the US dollar and Euro in the 2008-9 crisis that threatened the entire global financial system. At the same time, imbalances in rates of investment and consumption rates have opened contradictions within China's elites and urban and rural populations. Unlike Bond, Luce and Panitch, Katz's intention in his contribution is to differentiate China from the other BRICS states and each of them from the others. He also includes Turkey in his analysis of various categories within global capitalism.

Part Two's approach is mainly empirical as distinct from the theoretical-analytical method of Part One. It opens with a series of short articles on the exploitative nature of BRICS corporations in southern Africa in particular. These enterprises have, in the main, been extractivist not simply as exporters of mineral wealth but by virtue of such practices as transfer pricing and tax evasion. Two of the following articles examine Brazilian corporations in Africa (Garcia and Kato and Marshall) and in Canada (Marshall). Pedro Henrique Campos describes and analyses the rise of Brazilian multinationals in the heavy civil construction sector while Bonilla Martinez focuses on Chinese oil companies' exploration in the South American Andes region. Both articles expose the heavy state involvement in and support for corporate expansion and penetration of the host countries. Campos also shows how widespread this development has been: Brazilian civil construction companies found lucrative markets in the United States, the Middle East, and above all in Latin America and Africa. He argues that the influence of these companies on domestic and foreign policy guarantees the Brazilian economy a certain autonomy vis-à-vis the formerly dominant position of transnational corporations. 
The article by Braathen, Mascarenhas and Soederberg on the struggles in Rio that surrounded the Olympic Games project might better have been placed in Part 3 along with the articles on "BRICS from below" as it analyzes the popular uprising against the city manager's plans. The authors ponder whether this multi-faceted rebellion would qualify Rio as a "rebel city" in David Harvey's thinking. Also possibly out of place are the next two contributions that focus on Russian capitalism and on differentiating it from other BRICS' political economies as well as placing it in the context of global capitalism. Using a world system framework, Dzarasov characterizes Russian capitalism as semi-peripheral dependent capitalism while Pozo views Russia as a neo-liberal imperialistic power in its own right. Pozo describes its outreach in the formation of the Eurasian Economic Union yet he also emphasizes Russia's weakness and the contradictory nature of its imperialistic thrust. Similar to Bonilla Martinez and Pozo, he points out the symbiotic relations between corporations and the state but also underscores the distinctiveness of Russian capitalism in comparison with that of the other BRICS. In their insistence on an analytical-theoretical framework and the distinctiveness of Russian capitalism Dzarasov's and Pozo's contributions have more similarities with Katz's work in Part One than with the previous articles on corporate outreach and probably should have been placed there.

The first three articles of Part Three underline the difference between past imperialisms and the international economic order since World War II. Their concern is how the BRICS have inserted and asserted themselves in the contemporary system. Robinson's argument is that only a political economic analysis can reveal the underlying strategy inherent in BRICS countries' individual and group challenges to the international economic order. According to him, these challenges represent the jockeying of their elites for greater inclusion and influence within global capitalism. While for Robinson the international order is structurally made up of giant transnational corporations, for Elmar Altvater it is composed of nation-states and inter-state relations dominated by the United States backed by a neo-liberal ideology and military might. Through Atlantic and Pacific trade and investment areas, it seeks 
the continuing expansion of its national and transnational corporations. Altvater argues that these free trade agreements hold the potential for even further damage to the national environment as they promote ever-greater consumption of the earth's limited resources. The neo-liberal strategy is to turn natural limits into market opportunities: "environmental policy perfectly fits into the market system (243)" through such proposals as Reducing Emissions from Deforestation and Degradation (REDD), Payment for Ecosystem Services (PES) and so on. In turn, such projects legitimize the neo-extractivist policies practiced by the BRICS and others. Due to the pervasiveness of neo-liberalism, Altvater's vision for future global action on the limits of growth is bleak.

Moyo's and Yero's analysis of the contemporary global economy is nearer to that of Altvater than that Robinson and more nuanced than the latter's in that it recognizes relative autonomous behavior among individual BRICS countries, particularly China. They cite differences of participation in what they call the Western military project and also distinct "modes of engagement (249)" in Africa as examples. However, Moyo and Yeros are primarily interested in how an anti-systemic project can be promoted similar to that embodied in the Bandung Declaration of Non-Alignment. They suggest that the path forward is regional military pacts leading to new forms of regional integration.

The next eight articles focus on the paths actually taken by the BRICS as individual countries and as a collective. The incorporation of the BRICS in the G20 has led to adoption of a policy of financial inclusion aimed at offering credit and other policies for the poor as a means of poverty alleviation. Susanne Soederberg describes how this neo-liberal strategy has left the poor vulnerable to the cyclical crises of financial markets, which she argues, citing David Harvey, amounts to the "accumulation by dispossession."

Ho-fung Hung's article focuses on the role of China in maintaining the US dollar as the major international currency. He translates this as stabilizing the United States' position as the dominant international economic and military power despite its decline and China's own phenomenal economic growth. China's 
developmental model based on export-led growth has made it vulnerable to economic recession in its major Western markets.

Recognizing opposing views on the BRICS trajectory in the world order, Achin Vanaik in his short piece appraises their collective economic strength yet concentrates upon the internal contradictions underlying this growth that undermine their cohesion as a collective group. This makes him skeptical regarding the BRICS' reforming potential. In colorful non-academic language, Vijay Prashad describes what he sees as the dismal economic and political state of what he terms the Global South in contrast to the dominant G7. Prashad sees hope in the Bolivarian Alternative for the Americas (ALBA) approach that espouses "solidarity, cooperation, respect for sovereignty and uneven development (268)." He maintains that the BRICS should follow this route rather than seek inclusion in the dominant order.

Immanuel Wallerstein sees the entire world system in crisis. As an example, he cites, is the ever-declining rate of employment over the last 30-40 years. Political instability is another important factor particularly as US power declines, which has led to a multi-polar world. Wallerstein assesses the BRICS' role within it from a number of perspectives; he concludes it may be just a passing phenomenon. Reddy agrees with the majority of authors in Part Three that the BRICS' collective efforts do not represent a break with the existing system. Domestically, they are all capitalist economies pursuing political and foreign policies that are compatible with their domestic elites. He asserts that while their remarkable growth in political and economic structure may augur a more multipolar world structure, it will still remain a capitalist one.

The co-editors close the volume by demonstrating the relevance of the various positions on the BRICS outlined in their Introduction particularly in reference to recent BRICS summits. Far from being abstract academic categories, Patrick Bond illustrates their usefulness in clarifying the political realities of the 2015 summit where the "BRICS from Above" heads of state put the finishing touches on the New Development Bank and created a civic structure of "BRICS from the Middle" organizations close to government policy. Far from creating a rival to the IMF and World Bank, the leaders 
declared that the Bank's strategy would be cooperation with them. Bond shows how the new bank reinforces the multilateral financial organizations whereas the so-called Civic Structure's role is to legitimize rather than question the inter-governmental decisions. Both he and Ana Garcia argue the necessity of a "BRICS from Below" movement if these multilateral institutions and global capitalism are ever to be challenged. While Bond mentions a number of issues that have given rise to such transnational movements as the Climate Justice Campaign, he acknowledges that these are single-issue movements when what is needed is "civil society internationalism (295)." Garcia addresses the difficulties for countries with different histories and languages of the coming together of governmental and non-governmental institutions. Moreover, there are differences in outlooks on the collective role of the BRICS especially in reference to the New Development Bank evident in the 2013 and 2014 meetings of civil society representatives. However, Garcia insists that a common social strategy and struggle must be built upon the experiences of all in their separate national and international resistance to capitalist excesses.

The co-editors have done a remarkable job in bringing together an array of interpretations on the international political economy and the significance of the rise of the BRICS countries both individually and as a group. The book's cohesion lies in general agreement on depicting the world system as a global capitalist order still dominated by the United States/Western imperialism however much in decline. Yet there is much debate on what the BRICS actually represent. As just seen, the co-editors present an argument for the way forward, not simply in continuing the debate, but in building global resistance to the capitalist structure of the world political economy. As such, the book could be seen as an activist's handbook but it is much more. It should appeal to a wide variety of students in such fields as international relations, international economics, social change and development studies. Its wealth of information and data should also interest an even wider audience.

If there is any criticism I might offer, it concerns the internal organization of the volume. As already mentioned, there seems to be a disjoint in placing the articles of Dzarasov and Pozo in Part 
Two. Possibly combining these articles with that of Claudio Katz in a sub-section of Part One or even in a section on their own could enhance the book's coherence. Moreover, the book's subtitle is An Anti-Capitalist Critique, when what it presents is many such critiques. This was certainly a deliberate decision by the co-editors but one cannot help wondering if, beyond the summary they offer of the many articles, their conclusion should have engaged the various arguments in order to serve as a point of departure for student and activists alike in formulating their own critical thinking. 